\title{
The application of NPK fertilizer boosts the nutrient uptake status and biomass production of Vernonia amygdalina
}

\author{
DWI SUSANTO ${ }^{1, \boldsymbol{\nu}}$, RUDIANTO AMIRTA ${ }^{2}$ \\ ${ }^{1}$ Department of Biology, Faculty of Mathematics and Natural Sciences, Universitas Mulawarman. Jl. Barong Tongkok No. 4, Kampus Gunung Kelua, \\ Samarinda 75123, East Kalimantan, Indonesia. Tel.: +62- 541-749140, `email: susantodwiki@yahoo.com \\ ${ }^{2}$ Faculty of Forestry, Universitas Mulawarman. Jl. Ki Hajar Dewantara, Kampus Gunung Kelua, Samarinda 75123, East Kalimantan, Indonesia
}

Manuscript received: 30 July 2020. Revision accepted: 9 September 2020.

\begin{abstract}
Susanto D, Amirta R. 2020. The application of NPK fertilizer boosts the nutrient uptake status and biomass production of Vernonia amygdalina. Nusantara Bioscience 12: 114-119. Vernonia amygdalina Delile is a medicinal plant introduced in Indonesia. This study aims to determine the nutrients absorption status and growth of $V$. amygdalina plants planted with a spacing of $1 \mathrm{x} 1 \mathrm{~m}$. The study used a complete randomized block design with NPK compound fertilizer treatment with five doses of fertilizer namely $0 \mathrm{~g}$ (without fertilizer) as a control, $40 \mathrm{~g}, 80 \mathrm{~g}, 120 \mathrm{~g}$, and $140 \mathrm{~g}$, three blocks each group consisted of 10 plants so that in total there were 150 plants. The results showed that NPK fertilizer increased growth and the biomass of $V$. amygdalina. The best growth of $V$. amygdalina plant was achieved in plants applied with $160 \mathrm{~g}$ per plant NPK fertilizer in which the average of stem diameter and plant height were $6.69 \pm 0.930 \mathrm{~cm}$ and $611.67 \pm 12.71 \mathrm{~cm}$, while the estimated biomass yield was 407 tons.ha-1. The most nutritional elements accumulated in plant biomass was the calcium $\left(1279.49 \mathrm{~kg} \cdot \mathrm{ha}^{-1}\right)$, followed by magnesium $\left(1167.0642 \mathrm{~kg} \cdot \mathrm{ha}^{-1}\right)$, phosphorus $\left(536.64 \mathrm{~kg} \cdot \mathrm{ha}^{-1}\right)$, potassium $\left(419.71 \mathrm{~kg} \cdot \mathrm{ha}^{-1}\right)$ and nitrogen $\left(134.4 \mathrm{~kg} \cdot \mathrm{ha}^{-1}\right)$. We propose that these base nutrients are highly necessary for the cultivation of $V$. amygdalina as biomass feedstock or medicine plant.
\end{abstract}

Keywords: Biomass, NPK, nutrients uptake, Vernonia amygdalina

\section{INTRODUCTION}

Vernonia amygdalina Delile is one of the non-endemic plant collections from Cibodas Botanical Gardens, Cianjur, Indonesia originated from China, which was then firstly planted on 31 October 2009 (Lailaty and Nadhifah 2017). This plant is a small shrub, which has been widely planted by people in Indonesia, especially in East Kalimantan due to its potents as medicinal plants (Duarte and Silva 2013). This plant has potential as an antidiabetic drug (Atangwho 2014; Mustofa et al. 2020), antimalarial drug (Lailaty et al. 2016). It also contains antioxidative and chemopreventive properties (Farombi and Owoeye 2011; Asante et al. 2016; Okoduwa et al. 2017), antioxidants (Atangwho 2013), antibacterial (Uzoigwe and Agwa 2011), antifungal (Yusoff et al. 2018; Praptiwi et al. 2020). Moreover, this plant can be used as food supplements for chicken (Mandey et al 2010). Amirta et al. (2016) reported that $V$. amygdalina is woody plant that fastly grow, so that it is a prominent biomass plant to substitute the use of fossil fuels to produce heat and energy.

This plant can be propagated by stem cuttings (Ehiagbonare 2007; Anjula et al. 2014; Susanto et al. 2019a; Ma'rufah and Aziz 2019) and tissue culture (Eveline-Kong et al. 2016; Mey-Yin and Sani. 2018 ). The need of nutritional elements i.e cadmium and Lead to the soil affected the growth of 1-year-old $V$. amygdalina in terms of plant height, number of leaves, and number of branches, and stem diameter at the end of the experiment (Edegbai and Anoliefo 2019), whereas Nursuhaili et al.
(2019) report that administration of basic $\mathrm{N}$ fertilizers or basic fertilizers without $\mathrm{N}$ can be applied to $V$. amygdaline. In other parts, organic fertilizer such as chicken manure can be given at a dose of 2 tons per hectare, once a month. The effect of the reproductive phase on micronutrients has been reported by Musa et al. (2011), while the ability to accumulate heavy metals by $V$. amygdalina has been reported by Ikhajiagbe and Shittu (2016). On the other hand, the effect of water stress on $V$. amygdalina seedlings has also been reported by Osinaike et al. (2019). As an introduced plant that has spread widely in Indonesia, the information about this plant in terms of growth, biomass production and nutrient accumulation are not well known, yet. Therefore, the focus of this study was to determine the growth and nutrient accumulation of the $V$. amygdalina biomass by administering NPK compound fertilizer. This is of importance to investigate the accumulation status of nutrient elements in this plant biomass, which is necessary for large scale cultivation purposes.

\section{MATERIALS AND METHODS}

\section{Study area}

The research area is located at the coordinates $\mathrm{S}$ 00¹7'18.2 "and E 117 $14^{\circ} 39.5^{\prime}$ ", in Suka Damai Village, Muara Badak Sub-district, Kutai Kertanegara District, East Kalimantan Province, Indonesia (Figure 1). Planting was carried out from January 2018 to June 2019. Analysis of plant growth was carried out in the Plant Physiology 
Laboratory of the Faculty of Mathematics and Natural Sciences, while analysis of soil nutrient elements and plant biomass in the Soil ScienceLlaboratory of the Faculty of Forestry, Mulawarman University, Samarinda, East Kalimantan, Indonesia.

\section{Procedures}

\section{Seedling and land preparation}

The stem cuttings were taken from the $V$. amygdalina plant collection from the Plant Physiology laboratory, Faculty of Mathematics and Natural Sciences, Mulawarman University. Stem of $V$. amygdalina with a uniform diameter, a length of $50 \mathrm{~cm}$, planted into a polybag, and placed in a moist place. Three-month-old seedlings are ready to be moved to planting plots in the field.

Grasses that grow on the ground were cleaned manually, then made planting holes with a width of $30 \mathrm{~cm}$ and a depth of $30 \mathrm{~cm}$. Spacing of $1 \mathrm{~m} \times 1 \mathrm{~m}$ on an area of $360 \mathrm{~m} 2$. Before planting, the soil at the study site was sampled at a depth of $0-30 \mathrm{~cm}$ at four points. Soil composite samples were taken to the laboratory for analysis of its nutrient content

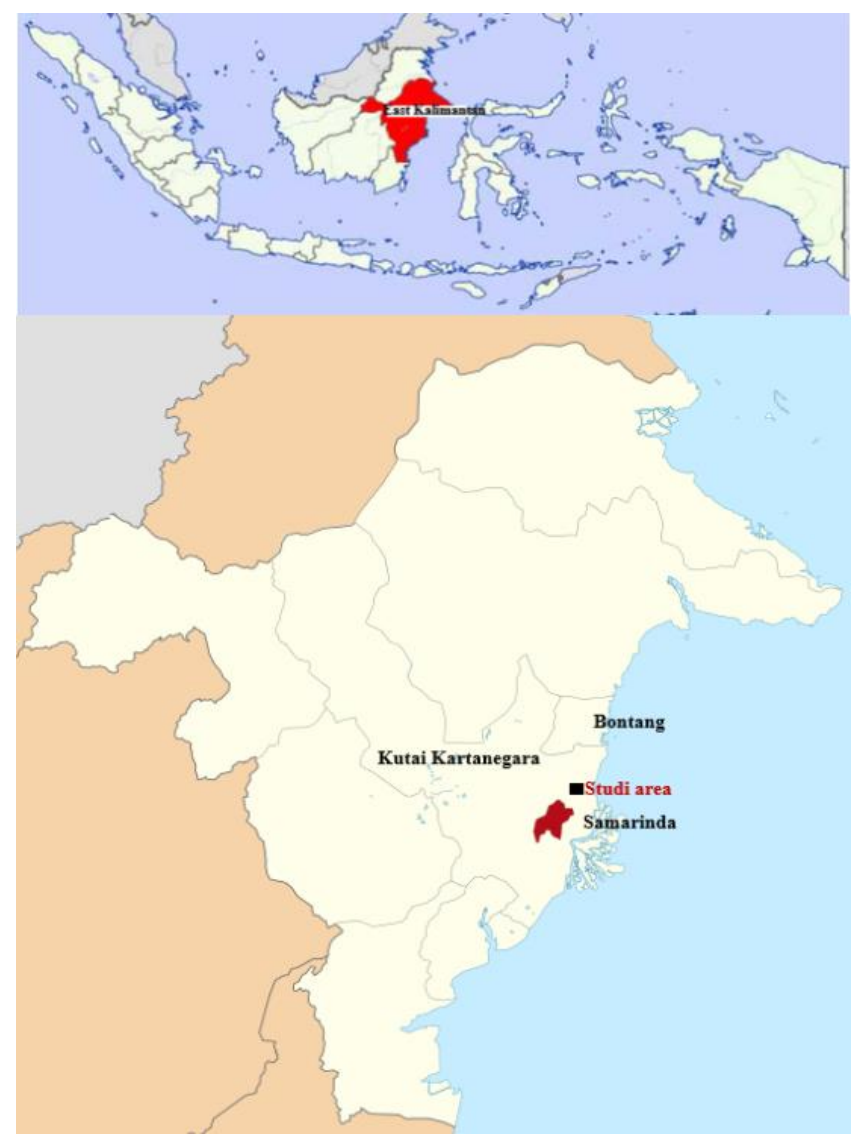

Figure 1. Map of research area in Suka Damai Village, Muara Badak Sub-district, Kutai Kartanegara District, East Kalimantan Province,Indonesia (Susanto et al.2019b).

\section{Experimental design}

The study design used a Complete Randomized Block Design, which consisted of five NPK fertilizer treatments, namely $0 \mathrm{~g}$ (without fertilizer as a control), $40 \mathrm{~g}, 80 \mathrm{~g}, 120$ $\mathrm{g}$, and $160 \mathrm{~g}$ respectively with 3 blocks, every 10 replications and total are 150 plants. Fertilization was done two weeks after planting with commercial NPK fertilizer by YARA, Oslo Norway: N (16\%), P (16\%), K (16\%), Mg $(1.5 \%)$ and $5 \% \mathrm{Ca}(5 \%)$ (Susanto et al. 2019a).

\section{Planting method}

Plants from stem cuttings are placed in prepared holes. The plant and the media are taken from the polybag carefully by tearing it with a knife. They are placed in holes and covered with soil. Two weeks after planting, each plant is fertilized using NPK fertilizer according to the stated concentration.

\section{Plant growth measurement}

Stem diameter, stem height, and the biomass of aerial part plants were measured as plant growth parameters. To analyze the chemical properties, leaf samples were collected in a composite from each treatment.

\section{Soil analysis}

Soil chemical dan physical properties analysis consisted of $\mathrm{pH}$, base saturation, cation exchange capacity, and bulk density. Nutrient concentrations such as total $\mathrm{N}$ (using Kjeldahl method), available $\mathrm{P}$ (using Bray method), and available $\mathrm{K}, \mathrm{Ca}$, and $\mathrm{Mg}$ (using spectrophotometrically) were measured at the laboratory (Susanto et al. 2019b).

\section{Analysis of nutrient concentration of plant components}

The Kjeldahl method (extraction, distillation, and titration) using to measure the total nitrogen concentrate. Phosphorus content was measured using a spectrophotometer at a wavelength of $470 \mathrm{~nm}$. Potassium, calcium, and magnesium were measured with Atomic Absorption Spectrophotometer. To calculate the total macronutrient elements, including $\mathrm{N}, \mathrm{P}, \mathrm{K}, \mathrm{Ca}$ and $\mathrm{Mg}$ accumulated in the three components in the stand, the dry weights of the three components were multiplied by their nutrient concentrations (Susanto et al. 2016).

\section{Data analysis}

Data were analyzed statistically using ANOVA to determine the significant difference between treatments and followed by Duncan's Multiple Range Test or DMRT (P = 0.1). All statistical tests used SPSS 23.0 (SPSS Inc. USA).

\section{RESULTS AND DISCUSSION}

\section{Soil chemical properties in the study area}

The chemical properties of the soil at this study site showed that the soil is acidic, the cation exchange capacity is low, the base saturation is high. Nitrogen, phosphorus, and potassium nutrients have low concentrations, while calcium and magnesium nutrient elements have high concentrations (Table 1). Zulkarnain et al. (2014) reported 
that bulk density soils ranged from $0.70-1.38$ g.cm ${ }^{-3}$, while Paranoan (2019) reported that the soil in Kutai Kartanehgara District is acidic ( $\mathrm{pH}$ 4.57-4.64), base saturation in the surface horizon content is moderate $(41.30 \%)$ and in the subsoil varies from low to very low (30.27 - 18.93\%). On the other hand, Susanto et al. (2019) reported that Soil in Muara Badak Sub-district, Kutai Kartanegara District is acidic, low cation exchange capacity (4.20), low base saturation, low available nitrogen, and low available potassium.

\section{Growth characteristics of Vernonia amygdalina}

ANOVA test showed that NPK compound fertilizer application affected the growth of stem diameter and plant height of $V$. amygdalina. The application of $160 \mathrm{~g}$ fertilizer per plant showed statistically significant from the control group and the administration of $40 \mathrm{~g}$ fertilizer. Applying 80 $\mathrm{g}$ and $120 \mathrm{~g}$ fertilizer was statistically not significant from the control group and $160 \mathrm{~g}$ on stem diameter. In plant height growth, applying $40 \mathrm{~g}, 80 \mathrm{~g}, 120 \mathrm{~g}$, and $160 \mathrm{~g}$ fertilizers were statistically significant from the control group. The application of $40 \mathrm{~g}$ fertilizer was statistically significant from application $80 \mathrm{~g}, 120 \mathrm{~g}$, and $160 \mathrm{~g}$. (Table 2). Study conducted by Payne (2011) showed no effect between plant spacing and plant height, wet weight, and dry weight of $V$. amygdalina plants. Susanto et al. (2019a) reported that at the age of 6 months after planting, several types of tropical shrub plants accumulated a lot of potassium, followed by nitrogen and phosphorus in the leaves. Kemka-Evans et al. (2014) reported that epidermal characters are of taxonomic importance in the classification and delimitation of the four taxa among the three species of Vernonia. On the other hand, Duarte and Silva (2013) reported that the leaf anatomy of $V$. amygdalina has stomata on both leaf surfaces so that it is more effective in absorbing $\mathrm{CO}_{2}$ gas for photosynthesis. Osinaike et al. (2019) reported that the best and favorable growth environment for $V$. amygdalina is watered every day. The amount of water available for plants will affect the rate of photosynthesis.

Table 1. The effect of fertilizer treatment on growth of basal stem diameter, stem height $V$. amygdalina. Values followed by the same letter within the same column do not differ significantly $(\mathrm{p}<0.10)$

\begin{tabular}{lll}
\hline Fertilizer & Basal diameter $(\mathbf{m m})$ & Height Stem $(\mathbf{c m})$ \\
\hline $0 \mathrm{~g}$ & $3.89 \pm 0.671^{\mathrm{a}}$ & $423.33 \pm 8.82^{\mathrm{a}}$ \\
$40 \mathrm{~g}$ & $4.88 \pm 0.104^{\mathrm{a}}$ & $473.33 \pm 14.53^{\mathrm{b}}$ \\
$80 \mathrm{~g}$ & $5.35 \pm 0.104^{\mathrm{ab}}$ & $553.33 \pm 24.17^{\mathrm{c}}$ \\
$120 \mathrm{~g}$ & $5.43 \pm 0.121^{\mathrm{ab}}$ & $561.67 \pm 20.88^{\mathrm{c}}$ \\
$160 \mathrm{~g}$ & $6.69 \pm 0.930^{\mathrm{b}}$ & $611.67 \pm 12.71^{\mathrm{d}}$ \\
\hline
\end{tabular}

\section{Nutrient concentration in biomass of Vernonia amygdalina aerial parts}

Nitrogen, phosphorus, calcium, and magnesium nutrients in stems have higher concentrations compared to leaves, while the concentration of potassium nutrients in stems is lower than in leaves. The highest nutrient concentrations in the stem are calcium (2.65-2.99\%), followed by magnesium $(2.08-2.80 \%)$, phosphorus (1.31$1.98 \%)$, potassium (1.01-1.21\%) and low levels are nitrogen (0.28-0.37). The highest concentration of nutrients in the leaves is potassium (1.22-1.32\%), followed by calcium (0.99-1.15\%), magnesium (0.57-0.75\%), phosphorus $(0.14-0.34 \%)$ and the lowest is nitrogen $(0.24-$ 0.32 ) \%) (Figure 2). Previous studies have shown that $V$. amygdalina leaves contain Calcium $145 \mathrm{mg}$, Phosphorus $0.7 \mathrm{mg} / 100 \mathrm{~g}$ dry weight (Sodimic et al. 2006). Edegbai and Anileofo (2019) reported that $V$. amygdalina was more uptake of lead than cadmium. On the other hand, Musa et al. (2011) reported that the concentrations of $\mathrm{Fe}, \mathrm{Mg}, \mathrm{Ca}$, and $\mathrm{K}$ decreased during the reproductive phase, however, the reduction of $\mathrm{Mg}$ was observed only with the applied nitrogen fertilizer. Tjhia et al. (2018) reported that the leaf concentrations of $\mathrm{N}, \mathrm{P}$, and $\mathrm{K}$ were higher in vegetative than in generative stage. Leaf nitrogen content increases chlorophyll a content, phosphorus is positively correlated with carotenoids, whereas potassium nutrient elements increase anthocyanin and chlorophyll a, chlorophyll b, and carotenoid content at the vegetative growth stage of $\mathrm{V}$. amygdalina plants. Carotenoids, chlorophyll a, chlorophyll b, anthocyanins are pigments that play a major role in plant photosynthesis. Fast-growing species Macaranga gigantea, endemic in Kalimantan has a nitrogen concentration of $1.51-1.89 \%$, phosphorus $0.14-0.16 \%$, and potassium 0.28 $0.38 \%$ in leaf organs, which is lower than the nutrient concentrations of $\mathrm{N}, \mathrm{P}$, and $\mathrm{K}$ in leaf $V$. amygdalina (Susanto et al. 2016; Susanto et al. 2017).

\section{The biomass production of Vernonia amygdalina}

ANOVA test showed that NPK compound fertilizer application increased biomass production of $V$. amygdalina plant. The application of $160 \mathrm{~g}$ fertilizer gave the highest biomass yield and statistically significant from the control group, application $40 \mathrm{~g}, 80 \mathrm{~g}$, and $120 \mathrm{~g}$ fertilizer. The highest biomass production in the application of $160 \mathrm{~g}$ fertilizer (407.55 tons.ha $\left.{ }^{-1}\right)$, followed by $80 \mathrm{~g}$ (232.69 tons.ha $\left.{ }^{-1}\right), 120 \mathrm{~g}$ (181.42 tons.ha $\left.^{-1}\right), 40 \mathrm{~g}$ (166.34 tons.ha $\left.{ }^{-1}\right)$, and lowest in the control group (121.46 tons.ha ${ }^{-1}$ ) (Figure 3). Macaranga gigantea plants treated with NPK fertilizer $120 \mathrm{~g}$ per plant (age 1 year) produced the highest biomass of 1,813 tons.ha- 1 . The production of $V$. amygdalina biomass is much higher (one hundredfold) compared to the production of Macaranga gigantea plant biomass, which is a fast-growing endemic plant from the island of Kalimantan (Susanto et al. 2017; Susanto et al. 2018). 

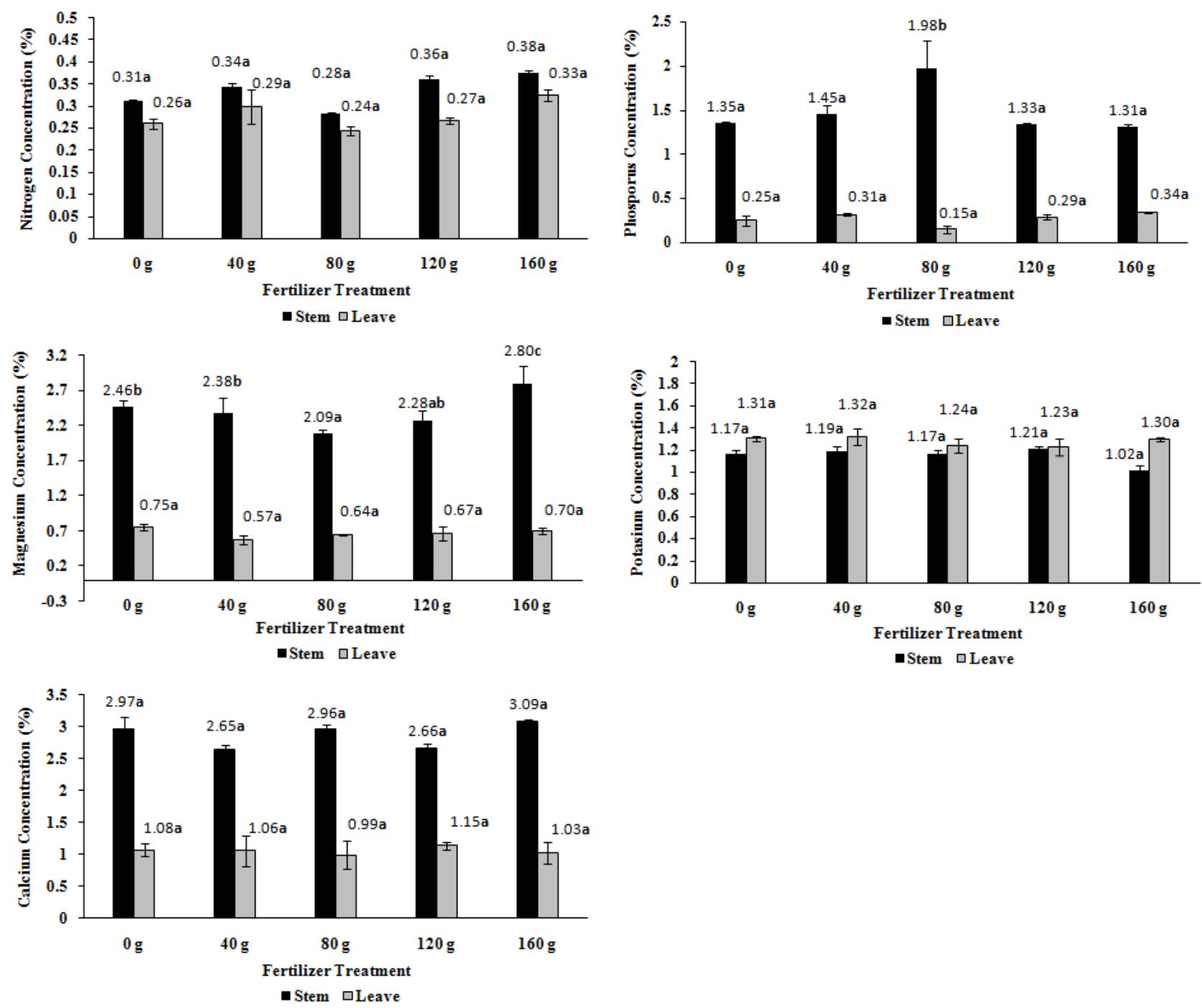

Figure 2. Effect of fertilizer treatment on concentration of $\mathrm{N}, \mathrm{P}, \mathrm{K}, \mathrm{Ca}$ and $\mathrm{Mg}$ on sample trees of Vernonia amiqdalina
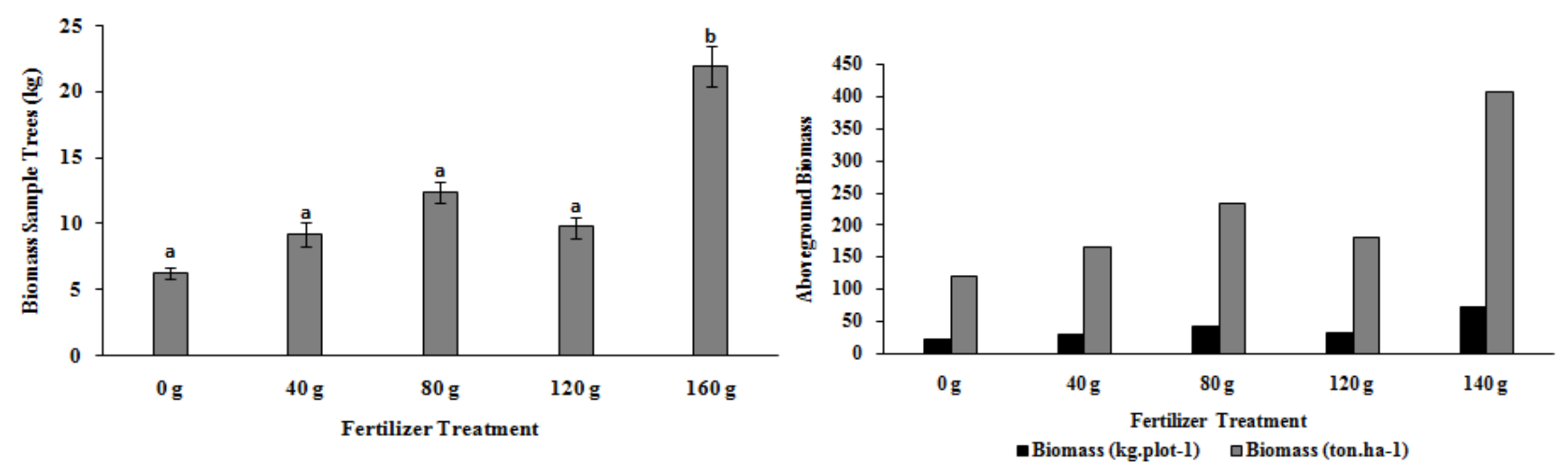

Figure 3. Biomass production of Vernonia amygdalina (A) on sample trees, (B) estimation per plot and per hectare 


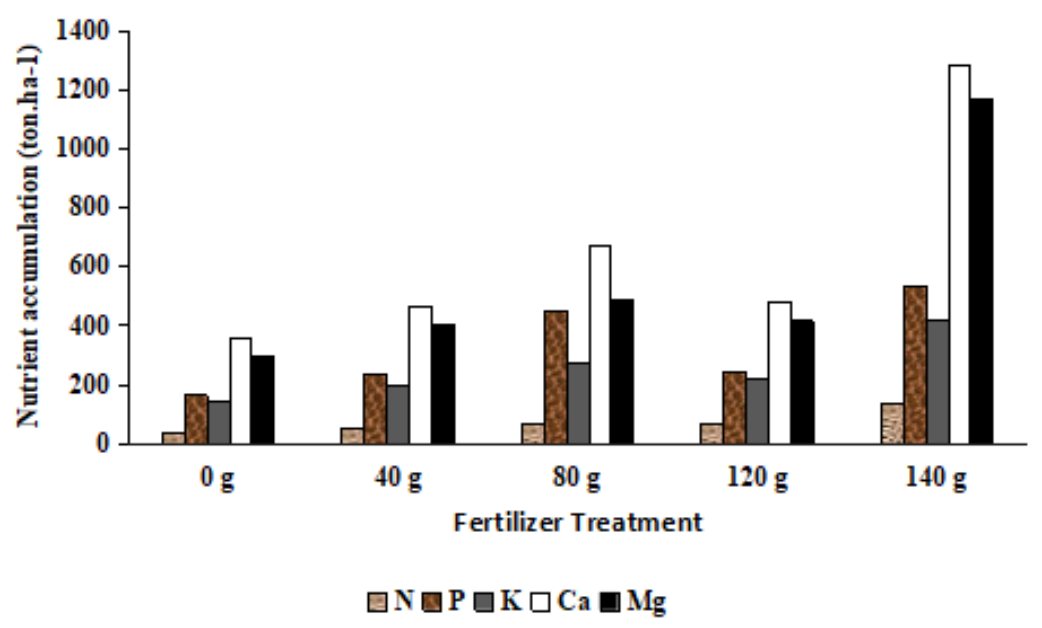

Figure 4. Estimation nutrient content accumulated in aboveground biomass of Vernonia amygdalina

\section{Nutrient uptake of Vernonia amygdalina}

Nutrients absorbed by plants will accumulate in the biomass component. The most nutrient elements that accumulate in $V$. amygdalina biomass are calcium, followed by magnesium, phosphorus, potassium and the lowest is nitrogen. The highest calcium nutrient accumulation in biomass was $1279.49 \mathrm{~kg}^{-\mathrm{ha}^{-1}}$ in the treatment of $160 \mathrm{~g}$ fertilizer and the lowest was 361.42 $\mathrm{kg} . \mathrm{ha}^{-1}$ in the control group without fertilizer application. The highest magnesium nutrient accumulation in the treatment of $160 \mathrm{~g}$ fertilizer is $1167.0642 \mathrm{~kg} \cdot \mathrm{ha}^{-1}$ and the lowest in the control group is $299.26 \mathrm{~kg} \cdot \mathrm{ha}^{-1}$. The highest accumulation of phosphorus nutrient elements was 536.64 $\mathrm{kg} \cdot \mathrm{ha}^{-1}$ and the lowest was $164.12 \mathrm{~kg} \cdot \mathrm{ha}^{-1}$, while the highest accumulation of potassium nutrient elements was 419.71 $\mathrm{kg} \cdot \mathrm{ha}^{-1}$ and the lowest was $141.41 \mathrm{~kg} \cdot \mathrm{ha}^{-1}$. In another part, the highest accumulation of nitrogen nutrient elements was 134.4 kg.ha- ${ }^{-1}$ and the lowest was 37.83 kg.ha-1 (Figure 4). Studies conducted on the Macaranga gigantea plant which is a fast-growing and endemic type of Borneo, showed that $M$. gigantea at the age of 1 year accumulated nitrogen nutrients $5.37 \mathrm{~kg} . \mathrm{ha}^{-1}$, phosphorus $14.35 \mathrm{~kg}^{-h^{-1}}$ and potassium $40.21 \mathrm{~kg} \cdot \mathrm{ha}^{-1}$, calcium $4.27 \mathrm{~kg} \cdot \mathrm{ha}^{-1}$, Magnesium $2.17 \mathrm{~kg} \cdot \mathrm{ha}^{-1}$ in the treatment of NPK or $120 \mathrm{~g}$ per plant (Susanto et al. 2017). Based on the comparison of the above data it can be seen that $V$. amygdalina plants absorb more nutrients than $M$. gigantea plants. This is thought to be caused by soil conditions, plant spacing, and genetic growth of $V$. amygdalina plants that grow fast and are able to absorb large amounts of nutrient elements, and produce a lot of biomass.

\section{ACKNOWLEDGEMENTS}

We thank all technicians from Plant Physiology Laboratory, Faculty of Mathematics and Natural Science and Soil Science Laboratory, Faculty of Forestry, Mulawarman University, Samarinda, Indonesia for helping us analyzed soil and plant tissue. We also thank our students for their help with the fieldwork in the research area.

\section{REFERENCES}

Amirta R, Angi EM, Ananto BR, Setiyono B, Haqiqi MT, Septiana HA, Lodong M, Oktavianto RN. 2016. Plant diversity and energy potency of community forest in East Kalimantan, Indonesia: Searching for fast-growing wood species for energy production. Nusantara Biosci 8 (1): 22-31.

Anjula P, Pradheep K, Neelam S.2014. Potential introduced medicinal plant African bitter leaf (Vernonia amygdalina Delile) in India: Botany, propagation and uses. Med Plants Intl J Phytomed Related Industr 6 (4): 272-276

Asante DB, Effah-Yeboah E, Barnes P, Abban HA, Ameyaw EO, Boampong JN, Ofori EG, Dadzie JB. 2016. Antidiabetic effect of young and old ethanolic leaf extracts of Vernonia amygdalina: A comparative study. J Diabetes Res 2016: 1-13.

Atangwho IJ, Yin KB, Umar MI, Ahmad M, Asmawi MZ. 2014. Vernonia amygdalina simultaneously suppresses gluconeogenesis and potentiates glucose oxidation via the pentose phosphate pathway in streptozotocin-induced diabetic rats. BMC Compl Altern Med 14: 426. DOI: $10.1186 / 1472-6882-14-426$.

Atangwho IJ, Egbung GE, Ahmad M, Yam MF Asmawi MZ. 2013. Antioxidant versus anti-diabetic properties of leaves from Vernonia amygdalina Del. growing in Malaysia. Food Chem 141 (4): 34283434 .

Duarte MR, Silva AG. 2013. Anatomical characters of the medicinal leaf and stem of Gymnanthemum amygdalinum (Delile) Sch. Bip. ex Walp. (Asteraceae). Braz J Pharm Sci 49 (4): 719-727.

Edegbai BO, Anoliefo GO. 2019. Growth and development of Bitter leaf (Vernonia amygdalina Del.) in soils treated with mixture of cadmium and lead. J Appl Sci Environ Manag 23 (5): 835-841.

Ehiagbonare JE. 2007. Vegetative propagation on some key malaria medicinal plants in Nigeria. Sci Res Essays 2 (2): 37-39.

Eveline-Kong YY, Sani H. 2016. Establishment of axenic explants and callus induction of Vernonia amygdalina Del. Borneo J Res Sci Technol 6 (2): 28-34.

Farombi EO, Owoeye O. 2011. Antioxidative and chemopreventive properties of Vernonia amygdalina and Garcinia biflavonoid. Intl J Environ Res Public Health 8: 2533-2555

Ikhajiagbe B, Shittu HO. 2016. Bioaccumulation of heavy metals by Vernonia Amygdalina in a waste engine oil-contaminated soil. J Sci Technol 4 (1): 94-103.

Kemka-Evans CE, Okoli B, Nwachukwu CU. 2014. Epidermal studies of three species of Vernonia Schreb. in Southern Nigeria. Biodiversitas 15 (2): $137-141$.

Lailaty IQ, Nadhifah A.2017. Pembungaan Vernonia amiqdalina koleksi Kebun Raya Cibodas, Jawa Barat. Prosiding Seminar Nasional Perhimpunan Holtikultura Indonesia, 11-12 Oktober 2017. [Indonesian]

Lailaty IQ, Muhaimin M, Handayani A, Efendi M, Nadhifah A, Noviady I. 2016. Potential of Cibodas Botanic Gardens plant collection as tehe future of antimalarial medicine. J Indon Med Plant 9 (1): 37-57 
Ma'rufah SH, Aziz SA. 2019. Growth response of Bitter leaf (Vernonia amygdalina cuttings and planting medium. Bul Agrohorti 7 (1): 53 61.

Mandey JS, Sompie M, Pontoh CJ. 2020. Nutrients and bioactive potency of bitter (Vernonia amygdalina) leaves as candidates for feedstuff and natural additives in broilers. Pros Sem Nas Masy Biodiv Indon 6 (1): 482-486.

Mei-Yin C, Sani H . 2018. In vitro plantlet regeneration from nodal explant and callus induction of Vernonia amygdalina Delile. J Plant Sci 6 (1): 1-6.

Musa A, Ogbadoyi EO, Johnson A. Oladiran, Ezenwa MIS, Akanya HO. 2011. Effect of reproductive phase on some micronutrients, antinutrients and toxins substances in Vernonia amygdalina grown in Mina, Niger State, Nigeria. Afr J Plant Sci 5 (9): 525-530

Mustofa FI, Rahmawati N, Aminullah. 2020. Medicinal plantsand practices of Rongkong Traditional Healers in South Sulawesi, Indonesia. Biodiversitas 21 (2): 642-651

Nursuhaili AB, Syahirah NAP, Martini MY, Azizah M, Mahmud TMM 2019. A review: Medicinal values, agronomic practices and postharvest handlings of Vernonia amygdalina. Food Res 3 (5): 380 390

Okoduwa SIR, Umar IA, James DB, Inuwa HM. 2017. Validation of the antidiabetic effects of Vernonia amygdalina Delile leaf fractions in fortified diet-fed streptozotocin treated rat model of type-2 diabetes. $\mathrm{J}$ Diabetol 8 (3): 74-85

Osinaike TS, Ezenwata IS, Anyaegbu CF, Onyemeka RM, Ogun ML, Akharia BE.2019. Effects of water stress on the morphologica growth of Vernonia amygdalina seedlings. Intl J Appl Sci Eng 4 (7): 222-228.

Paranoan RR. 2019. Chemical properties and mineralogical composition of soils in original site at coal mining area, East Kalimantan. Agritropica J Agric Sci 2 (2): 71-76.

Payne AL. 2011. Plant Density of (Vernonia Amiqdalina) on Growth, Biomass, and Mineral Content. [Thesis]. Master of Sciences in Agriculture, Alcorn State University, Mississipi.

Praptiwi, Fathoni A, Ilyas M. 2020. Diversity of endophytic fungi from Vernonia Amygdalina, their phenolic and flavonoid contents and bioactivities. Biodiversitas 21 (2): 436-441.

Sodimic AL, Adebayo O, Oladele NO, Akinyemi O, Alabi OO, Emeghara UU, Olumuyiwa S. 2006. Comparative analysis of chemica composition in three species of Bitter leaf (Vernonia spp). J. Res. Agric 3 (3): 75-77.

Susanto D, Hayatudin, Setiawan A, Purnomo H, Ruhiyat D, Amirta R. 2017. Characterizing nutrient status and growth of Macaranga gigantea in tropical rainforest gaps after selective logging in East Kalimantan, Indonesia. Biodiversitas 18 (3): 996-1003

Susanto D, Kusuma R, Amirta R. 2018. Nutrient distribution on soil and aboveground biomass of Macaranga gigantea five years after planting. Asian J For 2 (1): 12-19.

Susanto D, Mulyati S, Purnomo H, Ruhiyat D, Amirta R. 2017. Growth, biomass production and nutrient accumulation of Macaranga gigantea in response to NPK fertilizer application. Nusantara Biosci 9 (3): 330-337.

Susanto D, Ruhiyat D, Sutisna M, Amirta R. 2016. Soil and leaf nutrient status on growth of Macaranga gigantea in secondary forest after shifting cultivation in East Kalimantan, Indonesia. Biodiversitas 17 (2): 409-416.

Susanto D, Auliana A, Amirta R. 2019a. Growth evaluation of several types of energy crops from tropical shrubs species [version 1; peer review: 1 approved]. F1000Research 8: 329. DOI: 10.12688/f1000research.18063.1.

Susanto D, Kusuma R, Amirta R. 2019b. Effect of organic manure fertilizer on the growth of Macaranga gigantea. Nusantara Biosci 11 (2): 166-171.

Tjhia B, Aziz SA, Suketi K. 2018. Correlations between leaf nitrogen, phosphorus and potassium and leaf chlorophyll, anthocyanins and carotenoids content at vegetative and generative stage of Bitter leaf (Vernonia amygdalina Del.). J Trop Crop Sci 5 (1): 25-33.

Uzoigwe CI, Agwa OK. 2011.Antimicrobial activity of Vernonia amygdalina on selected urinary tract pathogens. Afr J Microbiol Res 5 (12): 1467-1472.

Yusoff SF, Mahmud TMM, Haron FF, Ismail SI, Sakimin SZ. 2018. InVitro antifungal activity of Vernonia amygdalina against Botrytis cinerea in tomato. In: Joint Symposium of the 8th International Agriculture Congress 2018 and 6th International Symposium for Food \& Agriculture 2018 (8th IAC-6th ISFA 2018). Universiti Putra Malaysia, 13-15 November 2018

Zulkarnain, Joy B, Tuhpawana P, Prawira I. 2014. Soil erosion assessment of the post-coal mining site in Kutai Kartanegara District, East Kalimantan Province. Intl J Appl Sci Eng 7 (2): 130-136. 